\title{
Hilsa fish: An endangered fish due to climat change and over exploitation
}

Q SUKANTA SARKAR

Article Chronicle :

Received:

23.01.2017;

Revised :

11.05.2017;

Accepted :

24.05.2017
ABSTRACT : Hilsa is into breeding migration in three major river systems of the Indo-Gangetic and Brahmaputra river network viz., Ganga, Brahmaputra and Meghna. In Persian Gulf this fish migrates to Arvand river and Bahmanshir river for spawning. The main peak season is September and October in all environments. Two to three years into their life cycle the hilsa migrate into the freshwater rivers upstream from the Bay of Bengal in order to spawn. The main objectives of this paper are: to study the situation of Hilsa in Bangladesh and India and to identify the reasons for reducing numbers of hilsa.

HOW TO CITE THIS ARTICLE : Sarkar, Sukanta (2017). Hilsa fish: An endangered fish due to climat change and over exploitation. Asian J. Environ. Sci., 12(1): 53-56, DOI: 10.15740/HAS/AJES/12.1/53-56.

Key Words : Hilsa, Bangladesh, Jatka, Migration, Fish, Fisherman

Author for correspondence : SUKANTA SARKAR Department of Economics, Berhampur University, ODISHA, INDIA 